\title{
Diversity of Insect Pollinators in Reference to Seed Set of Mustard (Brassica juncea L.)
}

\author{
Manju Devi $^{1 *}$, Harish Kumar Sharma ${ }^{1}$, Raj K. Thakur ${ }^{1}$, Satish K. Bhardwaj ${ }^{2}$, \\ Kiran Rana', Meena Thakur ${ }^{2}$ and Budhi Ram ${ }^{2}$ \\ ${ }^{1}$ Department of Entomology, ${ }^{2}$ Department of Environmental Science, Dr YS Parmar University \\ of Horticulture and Forestry, Nauni, Solan-173230, Himachal Pradesh, India \\ *Corresponding author
}

\section{A B S T R A C T}

The diversity of insect visitors on mustard (Brassica juncea L.) was studied at Dr.

Keywords

Diversity,

Pollinators insects,

Honeybees,

Brassica juncea,

Seed set.

Article Info

Accepted:

21 June 2017

Available Online:

10 July 2017
Y. S. Parmar University of Horticulture and Forestry Nauni, Solan. A total of 88 insects belonging to 63 genera under 31 families and 9 orders were found to visit the mustard bloom. Order Hymenoptera formed higher percentage of the insect visitors in scan sampling. Apis cerana and A. mellifera abundance were higher by scan sampling methods. Relative abundance (by scan sampling) and diversity (by sweep net method), in general, was statistically more at full bloom than at onset and end of bloom. Other dipterans were the dominant insect trapped in mustard crop by fluorescent pan trap. All the three methods namely fluorescent pan traps, scan sampling and sweep net method are essential for determining pollinator diversity as no single method is fully reliable. Highest seed set, seed siliqua ${ }^{-1}$ and 1000 seed weight was obtained by open pollination followed by hand pollination. The minimum seed set, seed siliqua ${ }^{-1}$ and 1000 seed weight was observed in case of pollinators exclusion.

\section{Introduction}

Agricultural production forms one of the most important economic sectors (FAOSTATS, 2013) where the quality of most crop species is increased by pollination (Klein et al., 2007; Gallai et al., 2009). Pollination is an important process in maintaining healthy and bio diverse ecosystems. Insects constitute one among the primary groups of pollinating agents, as the association between insects and flowers are well established. Insect pollination is important to the reproduction and persistence of many wild plants (Ollerton et al., 2011). Various insect groups, which are of prime significance in pollination of different agricultural, horticultural and medicinal herbal crops mainly belong to the orders Hymenoptera, Diptera, Coleoptera, Lepidoptera, Thysanoptera, Hemiptera and Neuroptera (Free, 1993; Kearns et al., 1998 ; Mitra and Parui, 2002; Mitra et al., 2008).

Brassica juncea is a self-incompatible crop due to which flowers cannot utilize their own pollen which needs biological agents like different insect groups for transfer of the pollen from male flowers to female flowers 
(Roy et al., 2014). Selfing in the absence of cross pollination generally reduces seed yield, seed size and yield in subsequent generation (Delaplane and Mayer, 2000). So far, honeybees alone are considered as significant pollinators on Brassica crop, however a number of other insects also visit on this crop during flowering period as reported by various workers from different parts of the country (Thakur et al., 1982; Bhalla, et al., 1983; Mishra et al., 1988; Prasad et al., 1989; Chaudhary 2001; Singh et al., 2004). Insect pollination in sarson, increase the seed yield, caused formation of well-shaped, larger grain, and more viable seed (Khan and Chaudhary, 1995).Here we analysed the diversity of pollinator insect in relation to seed set of mustard (B. juncea).

\section{Materials and Methods}

Studies on the insect pollinator diversity on mustard (Brassica juncea L.) were conducted during 2016 and 2016 at Baghor farm, Department of Entomology, Dr. Y. S. Parmar University of Horticulture and Forestry Nauni, Solan (Himachal Pradesh) situated at $33.3^{\circ} \mathrm{N}$ latitude, $70.70^{\circ} \mathrm{E}$ longitude and 1256 $\mathrm{m}$ amsl. The diversity of insect visitors on mustard was recorded by fluorescent pan traps, scan sampling and sweep net captures methods. Pan traps of florescent yellow, blue and white colour were used twenty four bowls, eight of each colour were used. These bowls were placed in three lines and the colours alternated throughout the transect. Traps were placed prior to $0900 \mathrm{~h}$ in the morning and removed after $1500 \mathrm{~h}$. Observations were recorded at onset of bloom, full bloom and end of bloom during three sunny days. The scan sampling was done by walking slowly along a set path in between rows. Number of insect visitors was recorded on 100 flowers in each of the 4 plots located in the experimental site on 3 sunny days. The insect visitors were counted by looking at individual flower one by one in sequences. The net sweeps were taken by transect walks between the ground flora. Five insect collection net sweeps were taken at all the random five spots equally distributed in the crop area. Observations for scan sampling and sweep net were recorded at onset of bloom, full bloom and end of bloom. Insect visitors were got identified from I.A.R.I., New Delhi.

The effect of insect pollination on setting was evaluated by allowing insect to visit on bloom by keeping plots open (OP), by caging the plots with muslin cloth (PE) and applying pollen by means of camel hair brush on emasculated flower (HP). Seed set was recorded on flower basis. The observations on seed set percentage for different modes of pollination was calculated as

Number of pods
Total numbers of flowers

Seed siliqua ${ }^{-1}$ and 1000 seed weight was calculated out for each modes of pollination. The data collected from field experiments were subjected to the analysis of variance following randomized block design.

\section{Results and Discussion}

The observations on insect visitors collected by different sampling methods in mustard crop revealed that 88 insects belonging to 63 genera under 31 families and 9 orders (Table 1) were collected on mustard crop. Hymenopteran were the most dominant order on mustard crop. Hymenopteran visitors (Fig. 1) belonged to twelve families namely Apidae (12), Andrenidae (2), Megachilidae (3), Halictidae (9), Pompilidae (1), Sphecidae (1), Formacidae (1), Ichneumonidae (1), Crabonidae (2), Tenthredinidae (1), Vespidae (1), Sphecidae (3) and Scoliidae (5). Apis 
cerana, A. mellifera, A. florea, A. dorsata, Ceratina sp., C. viridissima, $C$. hieroglyphica, C. smaragdina, C. sexmaculatus, Xylocopa amethystine, Crocisa ramose, and Bombus haemorrhoidalis represented the family Apidae. Andrenidae (Andrena sp., A. leaena). Megachilidae (Megachile sp., M. Fenestrate and M. flavipes), Halictidae (Halictus sp.1, Halictus sp.2, Halictus sp.3, Halictus sp.4, H. lucidipennis, Sphecodes sp., S. albifrons, S. ambuensis and Lasioglossum sp.). Pompilidae (Anoplius sp.) Sphecidae (Liris aurata), Crabonidae (Cerceris protea and Astata sp.), Tenthredinidae (Athalia proxima), Vespidae (Vespa sp.), Sphecidae (Podalonia sp., Sphex sp. and Sphex argentatus), Scoliidae (Scolia sp. 1, Scolia sp. 2, S. Quadripustulata and Campsomeris sp.) were also collected. Diptera (Fig. 2) were the second most dominant order with 16 specimen and four family. Eleven species were from familiy Syrphidae (Episyrphus balteatus, Sphaerophoria indiana, Eupeodes frequens, Metasyrphus confrater, Ischiodon scutellaris, Melanostoma univittatum, Scaeva sp., Eristalis sp., E. tenax, E. tabanoides, E. arvorum) and one species from Tephritidae (Bactrocera sp.) Calliphoridae (Chrysomya megacephala, Calliphora vicina) and Muscidae (Musca sp., Paragus rufuventris). Like Diptera, Lepidoptera had eighteen specimens, belonging to five families. Among Lepidopteran (Fig. 3) Amata bicincta (family Arctiidae) Colias electo edusina and Pieris brassicae, Gonepteryx rhamni (family Pieridae) Junonia sp., J. orithya ocyale, J. coenia, Neptis hylas, Symbrenthia lilaea Phalanta phalantha phalantha, Aglais cashmiriensis, Danus sp., D. Chrysippus, Vanessa cashmiriensis (Nymphalidae) Lampides boeticus, Lycaena phlaeas (Lycaenidae) and Helicoverpa armigera (Noctuidae) were also recorded. Insect from order Coleoptera, Neuroptera, Hemiptera, Thysanoptera, Odonata and Orthoptera were also sampled in mustard crop.
The results of the present investigation are almost similar to those reported by earlier workers. Kunjwal et al., (2014) observed a total of 30 species belonging to four orders Hymenoptera, Diptera, Lepidoptera and Coleopteran visiting mustard, $B$. juncea flowers. Among them, Hymenoptera were the major insect pollinators. It was also observed that $A$. mellifera was most abundant species in all the varieties of $B$. juncea than other bees. Kamel et al., (2015) observed 21 species of insect pollinators belonging to 14 families under four orders visiting canola, B. napus flowers. Ahmad (2005) reported that 22 and 16 Hymenopterans and 7 and 5 Dipterans species visiting mustard flowers in Diriyah and Derab (Saudi Arabia), respectively. They observed honey bees as the dominant Hymenoptera pollinators followed by other bees such as Andrena, Hexachysis, Osmia, Pompilus, Dieles and Wasps.

The sampled insects were arranged into seven different groups viz. A. cerana, A. mellifera, syrphids, other dipterans, wild bees, lepidopterans and other insect visitors. $A$. cerana and $A$. mellifera an individual species was kept as separate group amongst various visitors, because of its dominance. The results thus obtained for each of sampling method are given below

\section{Fluorescent pan traps}

Higher insect visitors were trapped at end of bloom (0.96 insects /trap) as compared to full bloom (0.65 insects /trap) (Fig. 4). Less number of insects was trapped at onset of bloom ( 0.40 insects /trap). This can be due to lack of flora at end of bloom and the insect visitors got attracted towards fluorescent pan traps and sink in to it. 
Table.1 List of insect collected by different sampling methods in mustard crop

\begin{tabular}{|c|c|c|}
\hline Order & Family & Scientific Name \\
\hline \multirow{38}{*}{ Hymenoptera } & \multirow{12}{*}{ Apidae } & Apis cerana Fabricius \\
\hline & & Apis mellifera Linnaeus \\
\hline & & Apis florea Fabricius \\
\hline & & Apis dorsata Fabricius \\
\hline & & Ceratina sp. \\
\hline & & Ceratina viridissima Dalla \\
\hline & & Ceratina hieroglyphica Smith \\
\hline & & Ceratina smaragdina Smith \\
\hline & & Ceratina sexmaculata Smith \\
\hline & & Xylocopa amethystina (Fabricus) \\
\hline & & Crocisa ramosa Lepeletier \\
\hline & & Bombus haemorrhoidalis Smith \\
\hline & \multirow[t]{2}{*}{ Andrenidae } & Andrena sp. \\
\hline & & Andrena leaena Caremon \\
\hline & \multirow[t]{3}{*}{ Megachilidae } & Megachile sp. \\
\hline & & Megachile flavipes Spinola \\
\hline & & Megachile fenestrate Smith \\
\hline & \multirow{9}{*}{ Halictidae } & Halictus sp.1 \\
\hline & & Halictus sp.2 \\
\hline & & Halictus sp.3 \\
\hline & & Halictus sp.4 \\
\hline & & Halictus lucidipennis Smith \\
\hline & & Sphecodes sp. \\
\hline & & Sphecodes albifrons Smith \\
\hline & & Sphecodes ambuensis Nurse \\
\hline & & Lasioglossum sp. \\
\hline & Pompilidae & Anoplius sp. \\
\hline & Sphecidae & Liris aurata Fabricius \\
\hline & Formicidae & Formica sp. \\
\hline & Ichneumonidae & Megarhyssa sp. \\
\hline & \multirow{2}{*}{ Crabonidae } & Cerceris protea Turn \\
\hline & & Astata sp. \\
\hline & Tenthredinidae & Athalia proxima Klug \\
\hline & Vespidae & Vespa sp. \\
\hline & \multirow{3}{*}{ Sphecidae } & Podalonia sp. \\
\hline & & Sphex sp. \\
\hline & & Sphex argentatus Fabricius \\
\hline & Scoliidae & Scolia sp.1 \\
\hline
\end{tabular}


Int.J.Curr.Microbiol.App.Sci (2017) 6(7): 2131-2144

\begin{tabular}{|c|c|c|}
\hline & & Scolia sp. 2 \\
\hline & & Scolia quadripustulata Fabricius \\
\hline & & Campsomeris sp. \\
\hline & & Dimorpha sp. \\
\hline \multirow{16}{*}{ Diptera } & \multirow{11}{*}{ Syrphidae } & Episyrphus balteatus (De geer) \\
\hline & & Sphaerophoria indiana Bigot \\
\hline & & Eupodus sp. \\
\hline & & Metasyrphus confrater (Wiedemann) \\
\hline & & Ischiodon scutellaris (Fabricius) \\
\hline & & Melanostoma univittatum Wiedemann \\
\hline & & Scaeva sp. \\
\hline & & Eristalis $\mathrm{sp}$. \\
\hline & & Eristalis tabanoides Jaennicke \\
\hline & & Eristalis arvorum (Fabricius) \\
\hline & & Eristalis tenax (Linnaeus) \\
\hline & Tephritidae & Bactrocera sp. \\
\hline & \multirow[t]{2}{*}{ Calliphoridae } & Calliphora vicina Robineau-Desvoidy \\
\hline & & Chrysomya megacephala (Fabricius) \\
\hline & \multirow[t]{2}{*}{ Muscidae } & Musca sp. \\
\hline & & Paragus rufuventris Brunetti \\
\hline \multirow{17}{*}{ Lepidoptera } & Arctiidae & Amata bicincta (Kollar) \\
\hline & \multirow{3}{*}{ Pieridae } & Colias electo edusina Felder \\
\hline & & Pieris brassicae (Linnaeus) \\
\hline & & Gonepteryx rhamni (Linnaeus) \\
\hline & \multirow{10}{*}{ Nymphalidae } & Junonia sp.1 \\
\hline & & Junonia sp.2 \\
\hline & & Junonia sp.3 \\
\hline & & Neptis hylas (Linnaeus) \\
\hline & & Symbrenthia lilaea (Hewitson) \\
\hline & & Phalanta phalantha phalantha (Drury) \\
\hline & & Aglais cashmiriensis (Kollar) \\
\hline & & Danus sp. \\
\hline & & Danus chrysippus (Linnaeus) \\
\hline & & Vanessa cashmiriensis Kollar \\
\hline & \multirow{2}{*}{ Lycaenidae } & Lampoides boeticus(Linnaeus) \\
\hline & & Lycaena phlaeas (Linnaeus) \\
\hline & Noctuidae & Helicoverpa $\mathrm{sp}$ \\
\hline \multirow{3}{*}{ Coleoptera } & \multirow{3}{*}{ Coccinelidae } & Hippodamia variegate (Goeze) \\
\hline & & Coccinella sepetempunctata (Linnaeus) \\
\hline & & Cheilomenes sexmaculata (Fabricius) \\
\hline
\end{tabular}




\begin{tabular}{|c|c|l|}
\hline \multirow{2}{*}{} & & Oenopia sp. \\
\cline { 2 - 3 } & Pyrrhocoridae & Dysdercus cingulatus (Fabricius) \\
\cline { 2 - 3 } & Tenebrionidae & Tribolium castaneum (Herbst) \\
\hline Neuropteran & Chrysopidae & Chrysoperla carnea (Stephens) \\
\hline \multirow{2}{*}{ Hemiptera } & Pentatomidae & Nezara viridula (Linnaeus) \\
\cline { 2 - 3 } & & Bagrada sp. \\
\hline Thysanoptera & Thripidae & Thrips sp. \\
\hline Odonata & Corduliidae & Neoconocephalus sp. \\
\hline \multirow{2}{*}{ Orthoptera } & Tettigonidae & Schistocera americana Drury \\
\cline { 2 - 3 } & Acrididae & \\
\hline
\end{tabular}

Table.2 Effect of different mode of pollination on seed set of mustard crop

\begin{tabular}{|l|c|c|}
\hline \multirow{2}{*}{ Modes of pollination } & \multicolumn{2}{|c|}{ Per cent seed set during } \\
\cline { 2 - 3 } Open Pollination (OP) & $\mathbf{2 0 1 5}$ & $\mathbf{2 0 1 6}$ \\
\hline Hand Pollination (HP) & $81.60(66.03)^{*}$ & $85.35(68.20)$ \\
\hline Pollinators exclusion (PE) & $55.60(48.22)$ & $56.85(48.95)$ \\
\hline Mean & $25.00(29.80)$ & $26.79(31.01)$ \\
\hline
\end{tabular}

$\mathrm{CD}_{(0.05)}$ Year (NS), Modes of pollination (6.34), Year x Modes of pollination (NS)

$*$ Figures in the parentheses are angular transformed values

Table.3 Effect of different mode of pollination on seed quality parameters in summer mustard crop

\begin{tabular}{|c|c|c|c|c|c|c|}
\hline \multirow{3}{*}{$\begin{array}{l}\text { Sowing } \\
\text { date }\end{array}$} & \multicolumn{6}{|c|}{ Different seed quality parameter } \\
\hline & \multicolumn{3}{|c|}{ Number of seed siliqua $^{-1}$} & \multicolumn{3}{|c|}{ weight of $1000 \operatorname{seed}(\mathrm{g})$} \\
\hline & 2015 & 2016 & Mean & 2015 & 2016 & Mean \\
\hline $\begin{array}{c}\text { Open } \\
\text { Pollination } \\
(\text { OP })\end{array}$ & 15.49 & 15.59 & 15.54 & 3.11 & 3.12 & 3.11 \\
\hline $\begin{array}{c}\text { Hand } \\
\text { Pollination } \\
\text { (HP) }\end{array}$ & 14.25 & 14.18 & 14.22 & 2.95 & 2.98 & 2.96 \\
\hline $\begin{array}{c}\text { Pollinators } \\
\text { exclusion } \\
\text { (PE) }\end{array}$ & 12.16 & 12.14 & 12.15 & 2.36 & 2.36 & 2.36 \\
\hline Mean & 13.97 & 13.97 & 13.97 & 2.81 & 2.82 & 2.81 \\
\hline $\mathrm{CD}_{(0.05)}$ & \multicolumn{3}{|c|}{ Year (NS), Modes of pollination (1.42), Year x Modes of pollination (NS) } & \multicolumn{3}{|c|}{ Year (NS), Modes of pollination (0.11), Year x Modes of pollination (NS) } \\
\hline
\end{tabular}


Fig.1 Important Hymenopteran species on Brassica juncea
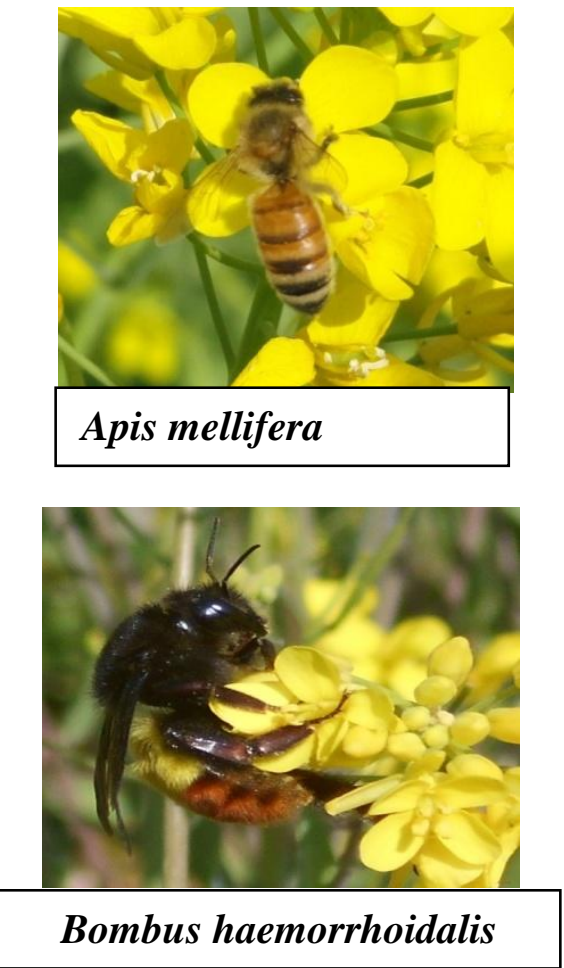
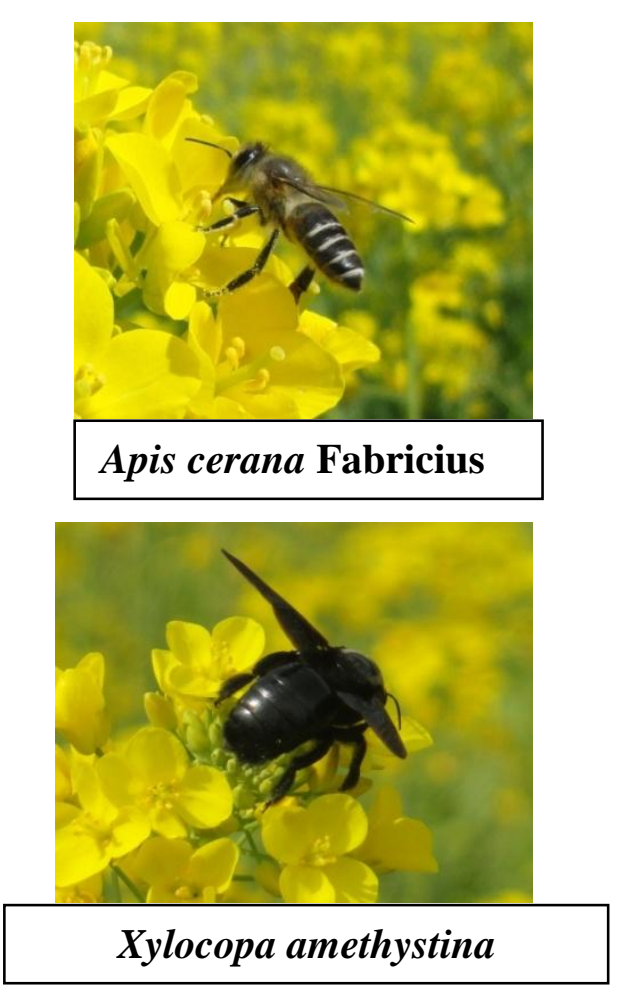
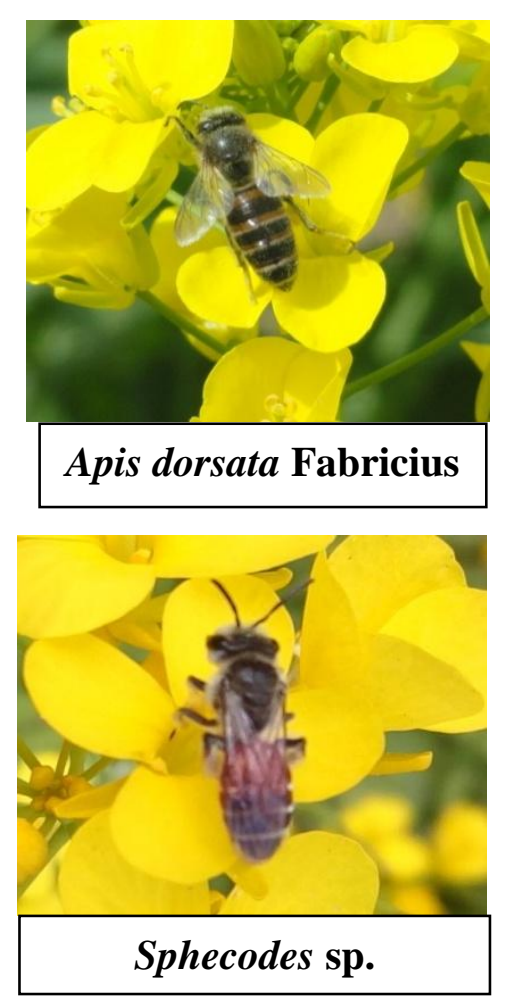
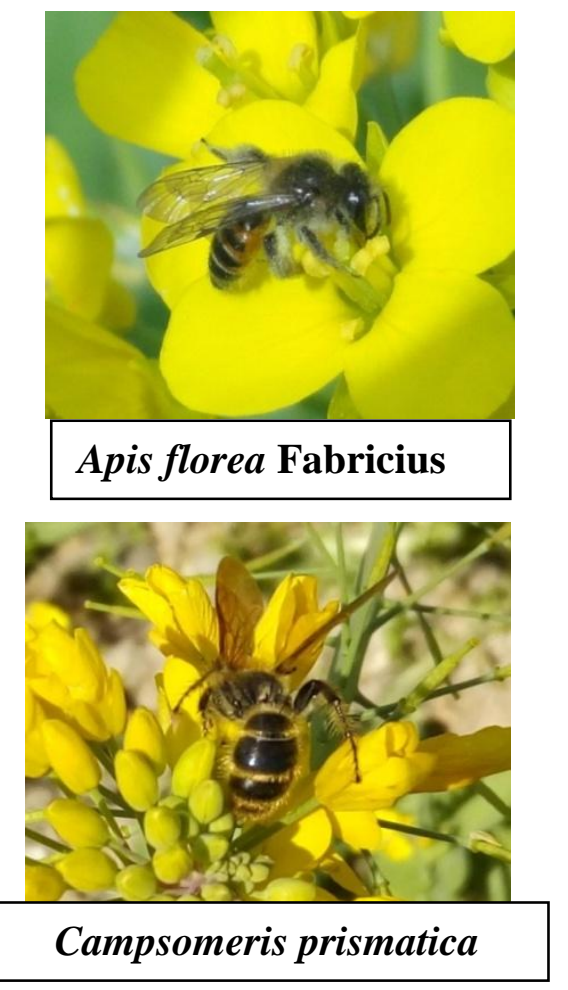
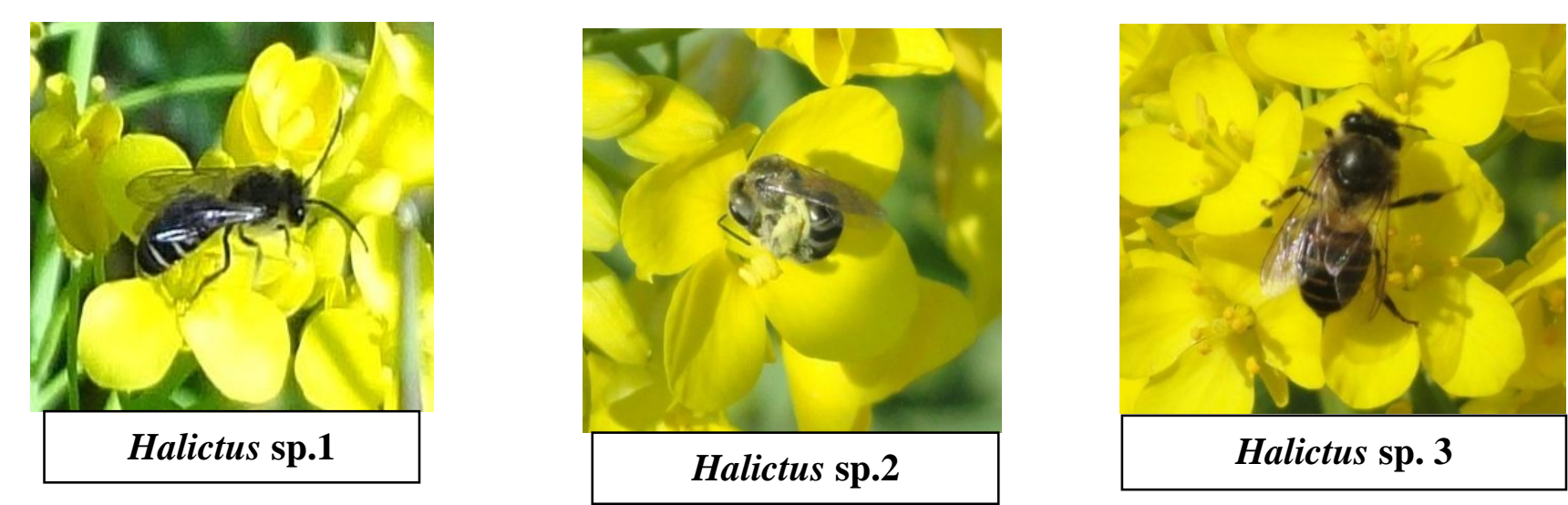

2137 
Fig.2 Important Dipteran species on Brassica juncea
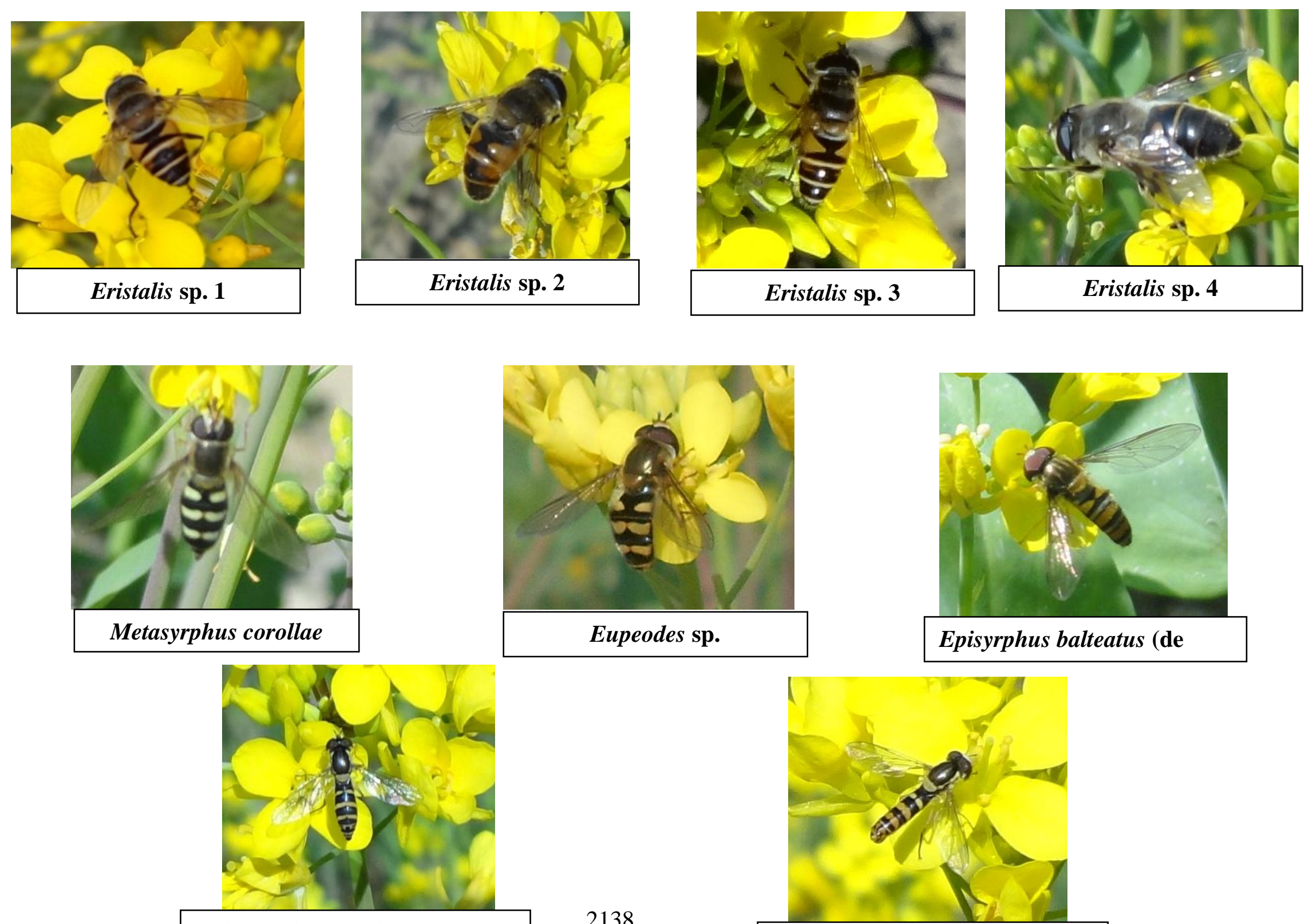

Sphaerophoria indiana Bigot 

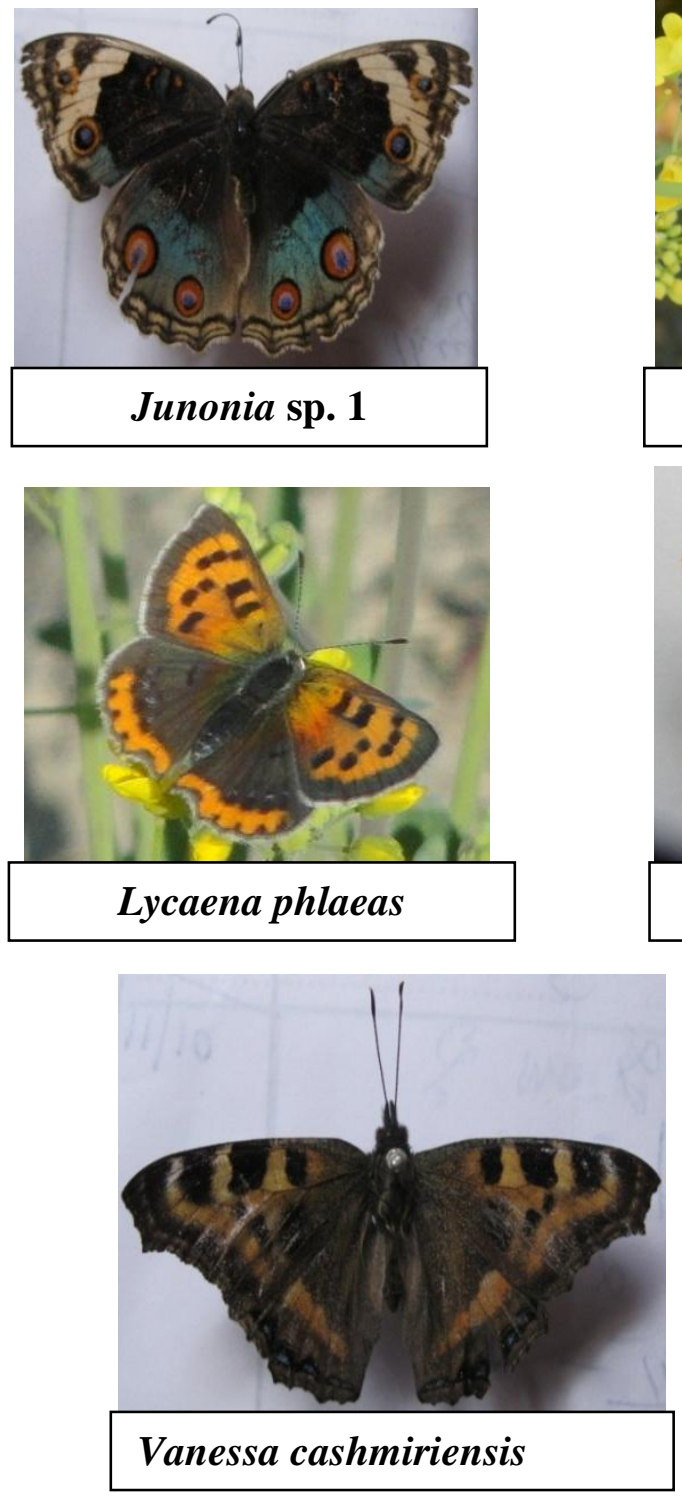

Fig.3 Important Lepidopteran species on Brassica juncea
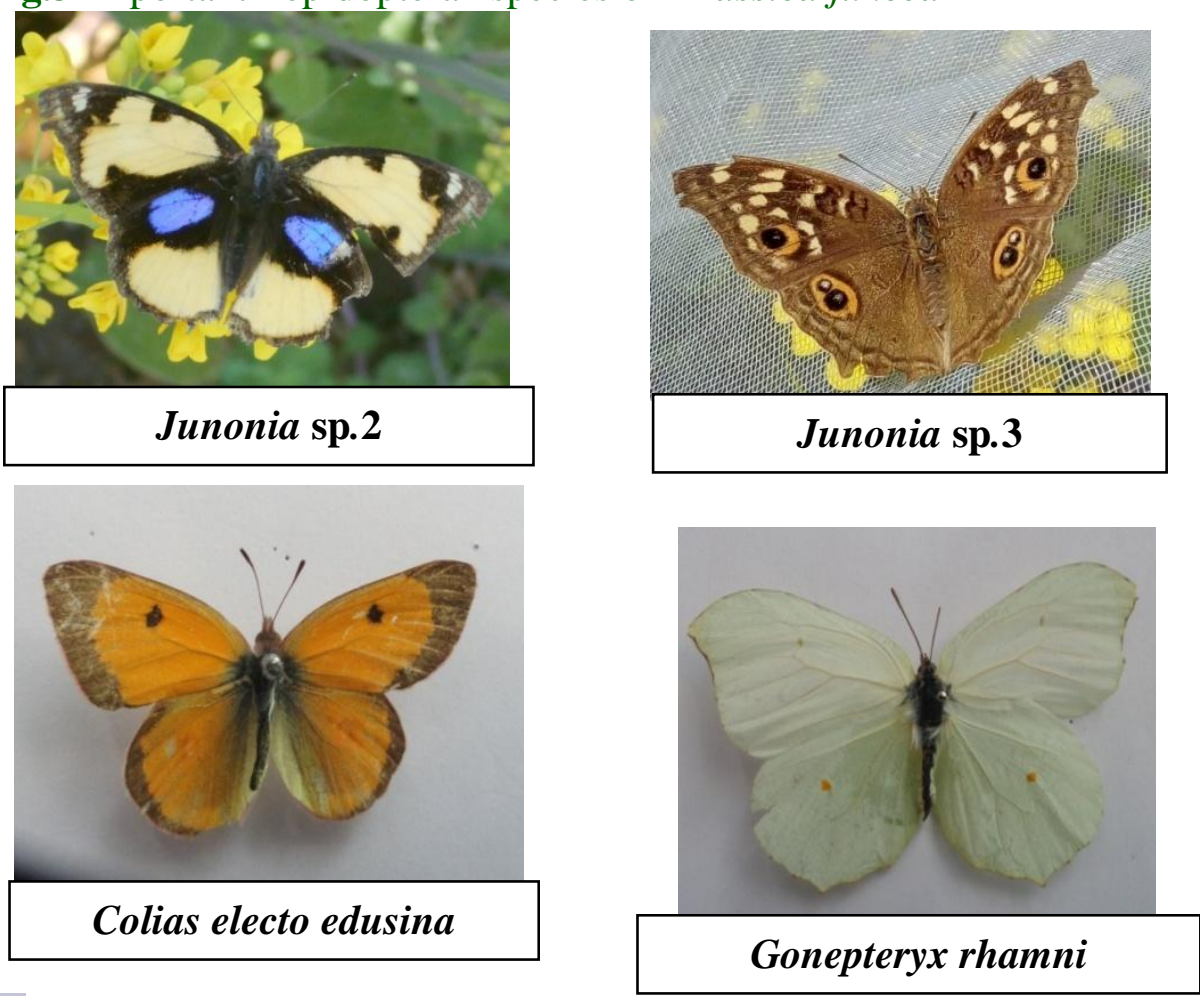

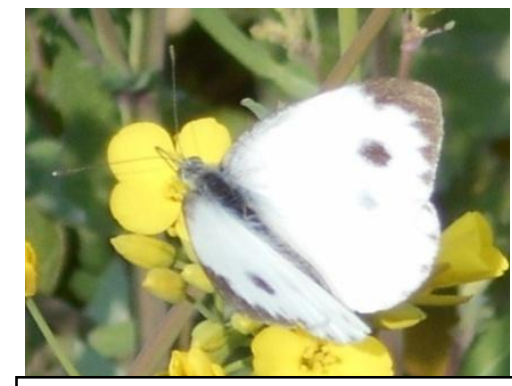

Pieris brassicae

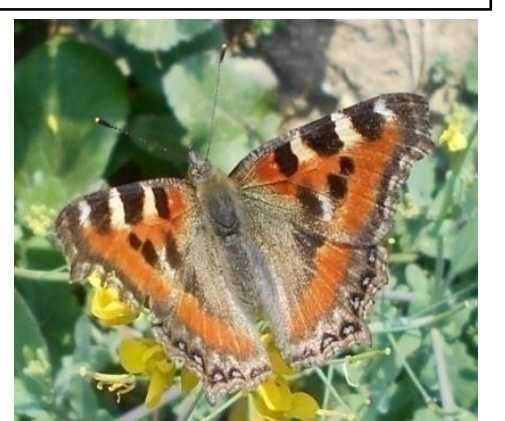

Aglais cashmiriensis
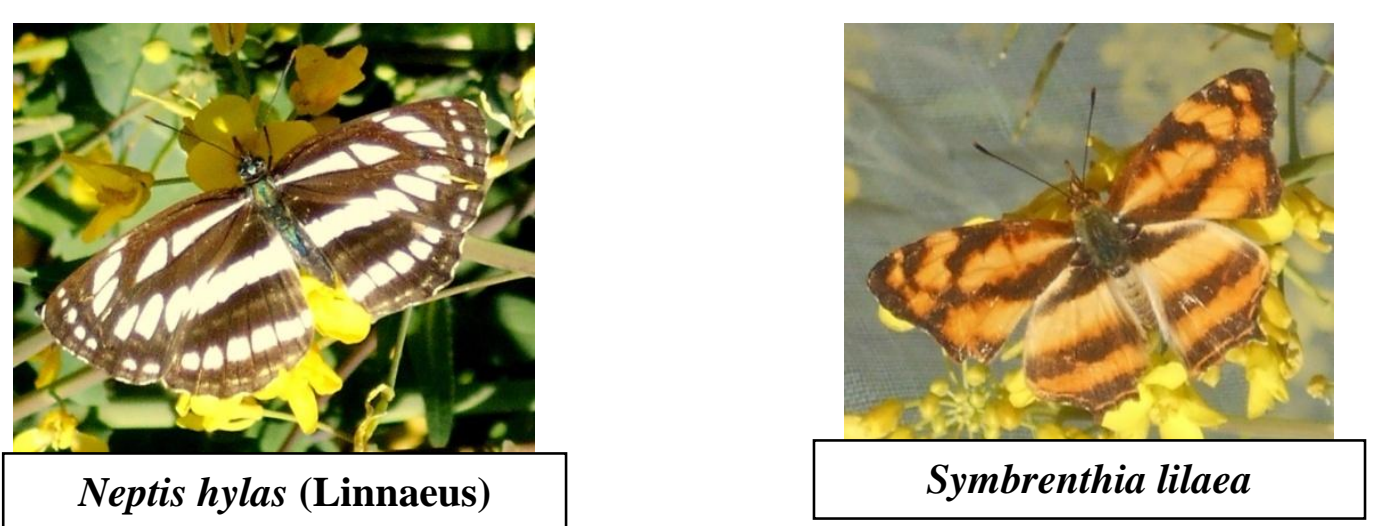
Fig.4 Number of insects by different sampling methods in mustard during different blooming stages

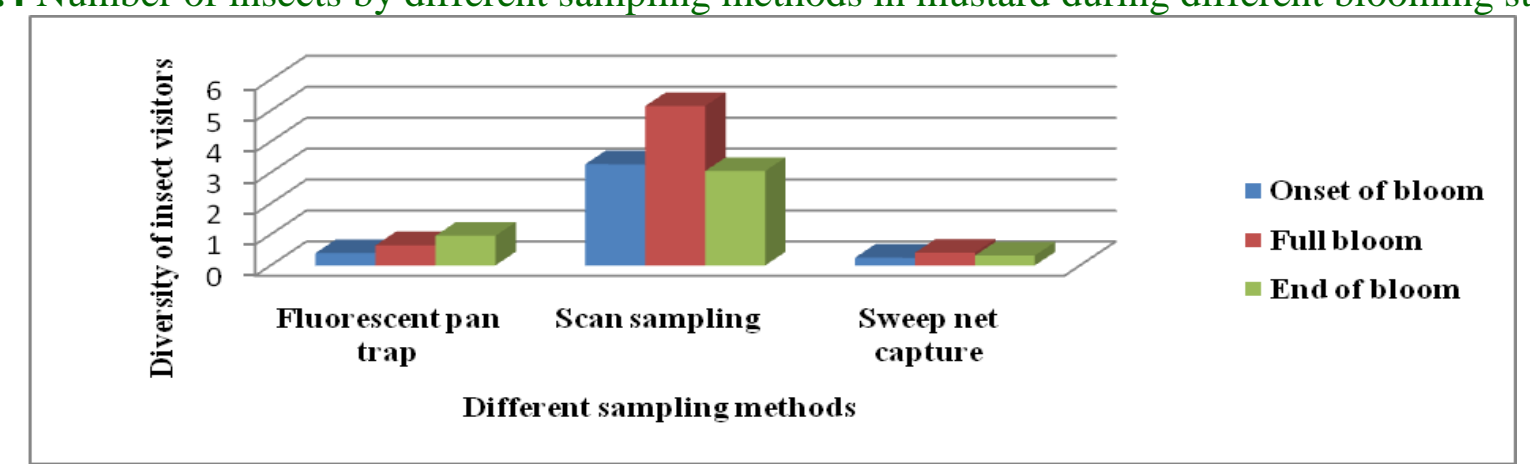

Fig.5 Diversity and abundance of insect visitors by different sampling methods

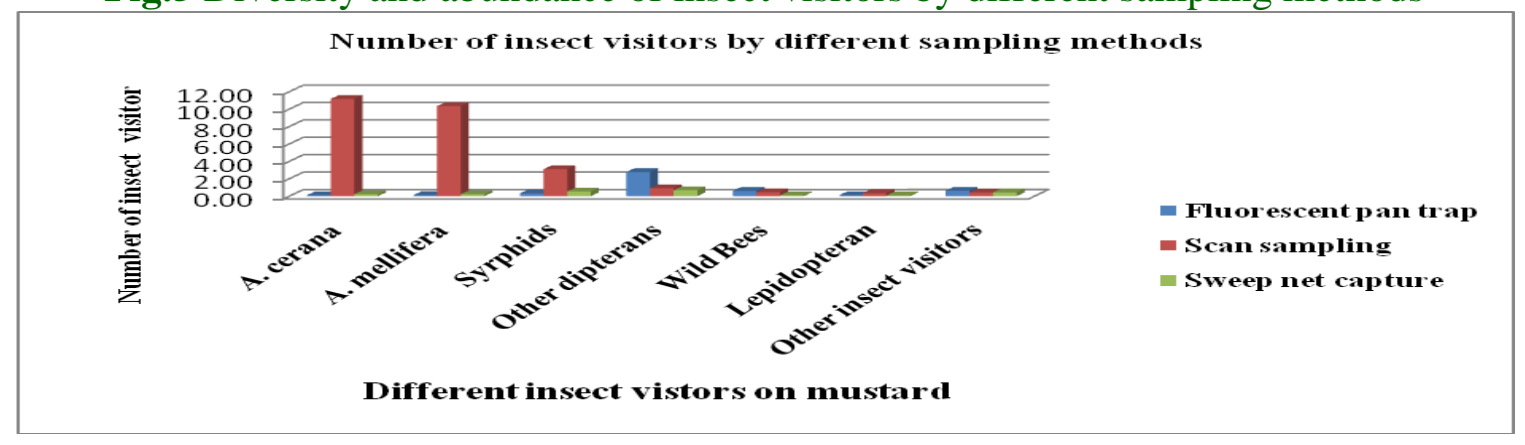

Fig.6 Effect of different mode of pollination on seed set of mustard crop

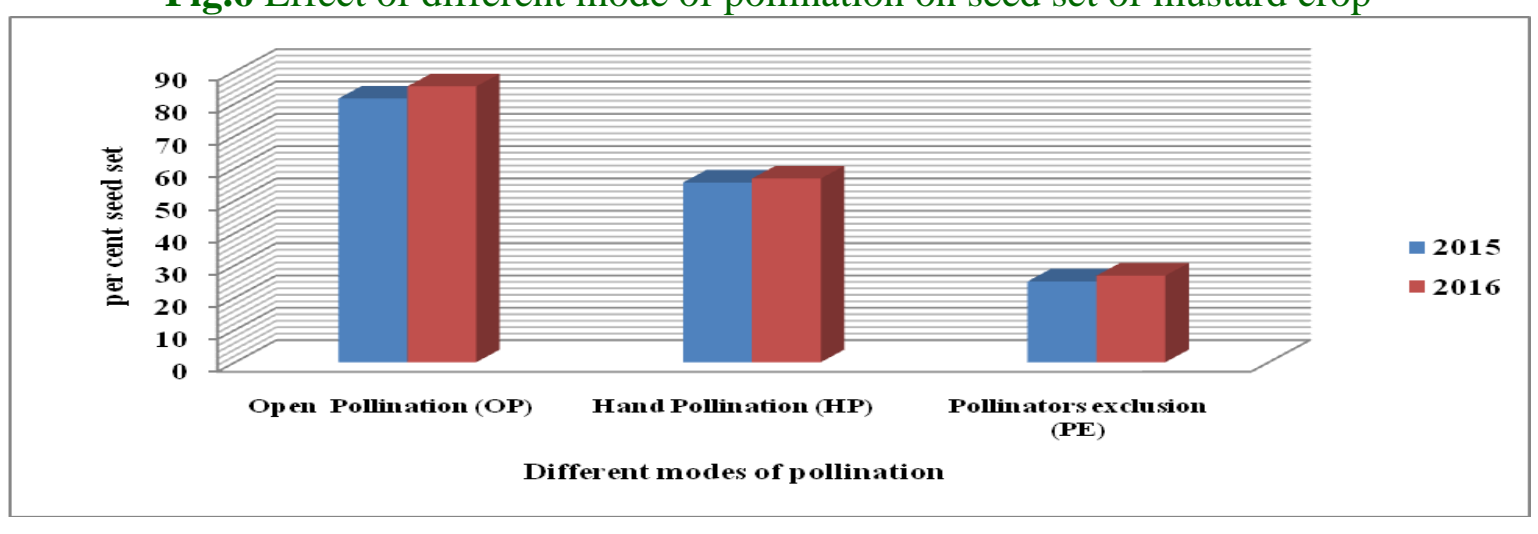


Other dipterans (2.78 insects /trap) found to be the most dominant visitors followed by other insect visitors (0.62 insects/trap) followed by wild bees ( $0.61 /$ insect trap). The number of trapped syrphids was 0.32insect/trap. Less number of trapped insects included A. cerana, A. mellifera and lepidopterans (Fig. 5). In the present investigation, other dipterans formed the large composition by fluorescent pan trap capture. Similar results were documented by Devi et $a l$. , (2015) that the number of other dipterans trapped (fluorescent pan trap) was maximum in coriander bloom.

\section{Scan Sampling}

The data (Fig. 4) elucidated that overall maximum mean population of insect visitors was observed at full bloom stage $(5.15 / 100$ flowers) followed by onset of bloom (3.27/100 flower) which was at par with end of bloom (3.65/100 flower). Among all insect visitors, A. cerana (11.18/ 100 flowers) was the most abundant visitors, followed by $A$. mellifera (3.22/ 100 flower) and syrphids (3.10/ 100 flower) and other dipterans (0.90/ 100 flower). Other insect visitors, wild bees and lepidopterans were least abundant insect groups on mustard bloom (Fig. 5). In our investigations the maximum number of insect visits the crop during peak flowering because the availability of flowers is more at that time. Therefore, the flower number clearly influences the pollinator's diversity and abundance and in turns the level of pollination. Plants with many flowers often attract more floral visitors than those with fewer flowers (Free, 1993).

\section{Sweep net captures}

Data revealed that like scan sampling method the insect visitors were higher at full bloom $(0.41 / 5$ sweeps $)$ compared to onset $(0.25 / 5$ sweeps $)$ and end of bloom (0.32/ 5 sweeps) in mustard crop (Fig. 4). Among all insect visitors other dipterans (0.68/ 5 sweeps) was dominant followed by syrphids (0.54/ 5 sweeps) and other insect visitors (0.44/ 5 sweeps). Diversity of $A$. cerana and $A$. mellifera was 0.23 and $0.22 / 5$ sweeps in mustard crop when computed by sweep net capture. The abundance of wild bee and lepidopterans was quite low (Fig. 5). These variations might be due to the methodology rather than presence or absence of particular flower visitors. The result of present investigations is in contrast to observation of Westphal et al., (2008) who reported that species composition of pan traps samples was very similar to the species composition of sample collected during transect walks. Insect species observed by different sampling methods also varied greatly. Great differences between the outcomes of pan traps and net collection have also been reported by Rounston et al., (2007). Insect visitors sampled by different sampling methods indicated that for sampling pollinator diversity all the methods have to be employed collectively as no single method is fully reliable. Pan traps have several known biases in catching less number of bumble bees and honeybees (Tolar et al., 2005). On the other hand pan traps are beneficial for catching small bee species that are often missed during transect walks, low in cost, reliable and simple to use. These can be used to attract pollinators in the absence of bloom and have no collector bias hence to characterize local bee fauna there is need to supplement pan trapping protocols with the other sampling method.

The impact of different mode of pollination showed that significantly highest percent seed set was in open pollination (81.60 and 88.35 $\%$ ) followed by hand pollination (55.60 and $56.85 \%)$.The minimum seed set was observed in pollinators exclusion (25 and $26.79 \%$ ) (Fig. 6, Table 2), during both the 
years of investigations (2015 and 2016). This study suggests that insect pollinators are playing an important role in seed set of mustard crop. The results of present investigation are in conformity with the earlier recorded observations of Tara and Sharma (2010) on Brassica campestris var. Sarson, which revealed that seed set, was less $(79.96 \%)$ in controlled experiment as compared to open pollinated flowers (88.05\%). Goswami and Khan (2014) also studied the impact of different modes of pollination in Mustard (Brassica juncea L.: Cruciferae and reported that highest percent pod set was in open pollinated $(83.42 \%)$ plots followed by bee pollinated $(75.41 \%)$ and caged pollinated $(62.80 \%)$ and recorded an increase of $8.09 \%$ pod set in open pollinated flowers as compared to controlled ones. Similar observations were also reported by Singh (1997) on Brassica juncea and Singh et al., (2004) on var. toria.

The data revealed that the seed siliqua ${ }^{-1}$ and 1000 seed weight were significantly higher in open pollination (15.49 and 15.59 seed siliqua $\left.^{-1}\right)$ followed by hand pollination (14.25 and 14.18 seed siliqua $^{-1}$ ) during 2015 and 2016, respectively (Table 3). Significantly less seed 12.16 and 12.14 seed siliqua ${ }^{-1}$ was recorded in pollinators' exclusion over the two tears of study. The present findings are in line with the findings of Kumari et al., (2013) who reported that the maximum number of pods per plant in Brassica juncea was observed in open pollinated plots which were significantly higher than that in A. mellifera pollinated plots and significantly the lowest were observed in pollinators' exclusion. Thakur and Karnatk (2005) reported that highest number of pods per plant in insect pollinated plants then caged plants without pollinators. Free and Nutall, 1968 observed that $B$. juncea plants caged with bees produced 25 per cent more seed than plant caged without bees. Parsad et al., (1989) found highest yield of $B$. juncea in open pollinated plot, whereas caged plots (excluding pollinators) yield the lowest.

The mean thousand weight of mustard seed was significantly more in open modes of pollination (3.11 and $3.12 \mathrm{~g}$ ) followed by that in hand pollination (2.95 and $2.98 \mathrm{~g}$ ) during 2015 and 2016. The lowest mean thousand seed weight $(2.36 \mathrm{~g})$ was recorded in pollinator's exclusion (Table 3 ) over the two year of study. The results of present investigation corroborate the observations made by Singh and Singh (1992) who reported that insect pollinated plots produced three times heavier seed then self-pollinated plants in B. campestris var. toria. The present findings are also corroborated by the results of Kamel et al., (2015) who observed that the weight of $100 \mathrm{o}$ seeds was higher in open pollinated plants $(3.13 \mathrm{~g})$ than those of caged plants $(2.4 \mathrm{~g})$ in B. napus.

In conclusion, the observations on diversity of insects by different sampling methods (fluorescent pan traps, scan sampling and sweep net) showed that large number of insect visitors is found visiting mustard bloom.

Hymenopterans pollinators were dominant amongst various pollinators and A. cerana and $A$. mellifera being dominant. The insect visitors were more abundant at full bloom stage. All the three methods namely fluorescent pan traps, scan sampling and sweep net method are essential for determining pollinator diversity as no single method is fully reliable. Highest seed set, seed siliqua $^{-1}$ and 1000 seed weight was obtained by open pollination followed by hand pollination. The minimum seed set, seed siliqua $^{-1}$ and 1000 seed weight was observed in case of pollinators' exclusion.

\section{Acknowledgement}

Authors are acknowledged to AICRP on honey bee and pollinators for providing 
financial and technical help. Authors are also thankful to Dr. Debjani Dey (Principal scientist, I.A.R.I., New Delhi) for identification of sample of insect pollinators.

\section{References}

Ahmad, A.A. 2005. Hymenopeterous and dipterous pollinators' diversity on various flowering plants in Riyadh, Saudi Arabia, Assiut J. of Agric. Scie., 36(1):69-83.

Bhalla O.P., Verma, A. K. and Dhaliwal, H.S. 1983. Insect visitors of mustard bloom (Brassica campestris var. sarson), their number and foraging behaviour under mid-hill conditions. J. of Entomo. Res., 7(1): 15-17.

Chaudhary, O. P. 2001. Abundance of wild pollinators on rapeseed and mustard. Insect Envir, 7(3): 141-142.

Delaplane K.S., Mayer, D.F. 2000. Crop pollination by bees. Oxon: CABI Publication, $352 \mathrm{p}$.

Devi, M., Sharma, H.K. and Rana, K. 2015. Measuring diversity and density of insect pollinators on coriander, Coriandrum sativum $\mathrm{L}$ by different sampling methods. Inter. J. of Farm Scien, 5(3): 179-189.

FAOSTATS: Food and agricultural organization of the United Nations. 2013. Statistical division. See http://faostats.fao.org/default.aspx.

Free, J.B. 1993. Insect Pollination of Crops. London, U.K. Academic Press, 684 p.

Free, J. B. and Nuttall, P.H. 1968. The pollination of oilseed rape (Brassica napus L.) and the behaviour of bees on the crop. J. of Agric. Scie., 71: 91-94.

Gallai, N., Salles, J.M., Settele, J., and Vaissiere, B.E. 2009. Economic valuation of vulnerability of world agriculture confronted with world pollinator decline. Ecolo. Econ., 68: 810-821.

Goswami, V. and Khan, M.S. 2014. Impact of honey bee pollination on pod set of mustard (Brassica juncea L.: Cruciferae) at Pantnagar. The Bioscan, 9(1): 75-78.

Kearns, C.A., Inouye, D.W., and Waser, N.M.
1998. Endangered mutualism: The conservation of plant pollinator interactions. Ann. Rev. of Ecol. Syst., 29: 83-112.

Kamel, S.M., Mahfouz, H.M., Blal, A., ElFatah, H., Said, M. and Mahmoud, M.F. 2015. Diversity of insect pollinators with references to their impact on yield production of canola (Brassica napus L.) in Ismailia, Egypt. Pesti. And Phytomed, 30(3): 161-168.

Khan, B.M., Chaudory, M.I. 1995. Comparative sssessment of honey bee and other insects with self-pollination of sarson (Brassica campestris) in Peshawar, Pakistan. In: Kevan PG (ed). The Asiatic hive bee: Apiculture, Biology and Rrole in Sustainable Development in Tropical and Subtropical Asia. Ontario: Enviroquest Ltd. 147-150 p.

Klein, A.M., Vaissiere, B.E., Cane, J.H., and Tscharntke, T. 2007. Importance of pollinators in changing landscapes for world crops. Proceedings of the Royal Society B: Biological Sciences, 274: 303313.

Kumari,S., Chhuneja, P.K. and Singh, J. 2013. Role of insect pollinators in seed yield augmentation of Brassica napus. In: Proceedings of $4^{\text {th }}$ International Congress on Insect Science, held at Banglore, India. $66 \mathrm{p}$.

Kunjwal, N., Kumar, Y. and Khan, M.S. 2014. Flower visiting insect pollinators of brown mustard Brassica juncea L. Czen and cross and their foraging behaviour under caged and open pollination. Afr. $J$. of Agric. Res., 9(16): 1278-1286.

Mishra, R. C., Kumar, J. and Gupta, J. K. 1988. The effect of mode of pollination on yield and oil potential of Brassica campestris L. var. sarson with observations on insect pollinators in Himachal Pradesh, India. J. of Apicul. Res., 27(3):186-189.

Mitra, B., and Parui, P. 2002. New record of entomofauna from Thar Desert. Ins. Envi., 8: 115-116.

Mitra, B., Banerjee, D., Mukherjee, M., Bhattacharya, K., and Parui, P. 2008. 
Flower visiting flies (Diptera: Insecta) of Kolkata and Surroundings, (Pictorial handbook). India: Zoological Survey of India (ZSI), Kolkata.

Ollerton, J., Winfree, R., and Tarrant, S. 2011. How many flowering plants are pollinated by animals? Oikos, 120: 321-326.

Parsad, D., Hameed, S.F., Singh, R., Yazdani, S.S. and Singh, B. 1989.Effect of bee pollination on the quantity and quality of rai crop, (Brassica juncea Coss.). Ind. Bee J., 51(2): 45-47.

Roulstone, T.H., Smith, S.A. and Brewster, A.L. 2007. A comparison of pan trap and intensive net sampling techniques for documenting a bee (Hymenoptera: Apiformes) fauna. $J$. of the Kansas Entom. Soc., 80: 179-81.

Roy, S., Gayen, A.K., Mitra, B. and Duttagupta, A. 2014. Diversity, foraging activities of the insect visitors of Mustard (Brassica juncea $\mathrm{L}$,) and their role in pollination in West Bengal. The J. of Zool. Stud., 1(2): 7-12.

Singh, Y. 1997. Role of honey bees in farm production, agricultural growth and rural reconstruction in India. Ind. Bee J., 59(1):24-30.

Singh, R.P. and Singh, P.N.1992. Impact of bee pollination on seed yield, carbohydrate composition and lipid composition of mustard seed. J. of Apicul. Res., 31(3-4): 128-133.

Singh, B., Kumar, M., Sharma, A. K. and Yadav, L. P. 2004. Effect of bee pollination on yield attributes and seed yield of toria (Brassica campestris var. toria) in Pusa, India. Envir. And Ecol., 22(3): 571-573.

Thakur, A. K., Sharma, O. P., Garg, R. and Dogra, G. S. 1982. Camperative studies on foraging behavior of Apis mellifera and Apis cerana indica on mustard. Ind. Bee J., 44(4): 91-92.

Thakur, S. S. and Karnatak, A. K. 2005. Impact of insecticides and mode of pollination on yield components of Brassica campestris with assessment of insecticidal toxicity influencing behaviour of Apis mellifera $\mathrm{L}$. Thesis (Ph.D. Entomology) submitted to G.B.P.U.A. and T. Pantnagar - 263 145, (U.S. Nagar), Uttarakhand, India.

Tara, J.S. and Sharma, P. 2010. Role of honeybees and other insects in enhancing the yield of Brassica campestris var. Sarson. Halteres, 1(2): 35-37.

Tolar T.R, Evanas EW and Tepedino V.J. 2005. Pan traps for bees (Hymenoptera: Apiformes) in Utah's West Desert: the importance of colour diversity. Pan Pac. Entomol, 81: 103-113.

Westphal C., Bommarco R., Carre, G., Lamborn, E., Morison, N., Petanidou, T., Potts, S.G., Roberts, S.P.M., Szentgyorgyi, H., Tscheulin, T., Vaissiere, B.E., Woyciechowski, M., Biesmeijer, J.C., Kunin, W.E., Settle, J. and Dewenter, I.S. 2008. Measuring bee diversity in different European habitats and bio geographical regions. Ecol. Monogr., 78: 653-671.

\section{How to cite this article:}

Manju Devi, Harish Kumar Sharma, Raj K. Thakur, Satish K. Bhardwaj, Kiran Rana, Meena Thakur and Budhi Ram. 2017. Diversity of Insect Pollinators in Reference to Seed Set of Mustard (Brassica juncea L.). Int.J.Curr.Microbiol.App.Sci. 6(7): 2131-2144. doi: https://doi.org/10.20546/ijcmas.2017.607.250 